\title{
Analisis pengaruh modal usaha, umur, pendidikan dan jam kerja terhadap pendapatan pedagang pasar tradisional di Desa Sungai Saren Kecamatan Bram Itam Kabupaten Tanjung Jabung Barat
}

\author{
Selamat Rianto; *Zulgani; Purwaka Hari Prihanto
}

\author{
Prodi Ekonomi Pembangunan, Fak. Ekonomi dan Bisnis, Universitas Jambi \\ *Email Korespondensi: gzulgani@gmail.com
}

\begin{abstract}
This study aims to analyze the effect of capital, age, education and working hours on the income of traditional market traders in Sungai Saren Village, Bram Itam District, Tanjung Jabung Barat Regency. The data used in this study are primary data, the sampling method used in this study is Purposive Sampling with 56 respondents as traders, the analytical tool used is Multiple Linear Analysis.Based on the results of the study obtained a probability value of 0,000 for the $F$ Test and partial test of Capital, Age, Education and Working Hours variables. This shows that the variables simultaneously and partially all the variables have a significant effect on the income of Traders in the Traditional Market of Sungai Saren, Bram Itam District, Tanjung Jabung Barat Regency. Determination Coefficient Value (R2) of 0.520 shows that the influence of Capital, Age, Education and Working Hours, Work on the income of Traders of Sungai Saren Market, Bram Itam District, Tanjung Jabung Barat Regency is 52\%.
\end{abstract}

Keywords: Trader Income, Capital, Age, Education, Working Hours

\begin{abstract}
Abstrak
Penelitian ini bertujuan untuk menganalisis Pengaruh Modal, Umur, Pendidikan dan Jam Kerja terhadap Pendapatan Pedagang Pasar Tradisional di Desa Sungai Saren Kecamatan Bram Itam Kabupaten Tanjung Jabung Barat. Data yang digunakan dalam penelitian ini adalah data primer, metode penarikan sampel yang digunakan yang digunakan dalam penelitian ini adlah Purposive Sampling dengan jumlah responden sebanyak 56 orang pedagang, alat analisis yang di gunakan adalah Analisis Linier Berganda.Berdasarkan hasil penelitian diperoleh nilai probabilitas 0,000 untuk Uji $F$ dan uji secara parsial variabel Modal, Umur, Pendidikan dan Jam Kerja. Ini menunjukkan variabel secara simultan dan parsial semua variabel berpengaruh signifikan terhadap Pendapatan Pedagang Pasar Tradisional Sungai Saren Kecamatan Bram Itam Kabupaten Tanjung Jabung Barat. Nilai Koefisien Determinasi $\left(\mathrm{R}^{2}\right)$ Sebesar 0,520 menunjukkan bahwa pengaruh Modal, Umur, Pendidikan dan Jam Kerja, Kerja terhadap pendapatan Pedagang Pasar Sungai Saren Kecamatan Bram Itam Kabupaten Tanjung Jabung Barat adalah Sebesar 52\%.
\end{abstract}

Kata Kunci: Modal, Umur, Pendidikan, Jam Kerja 


\section{PENDAHULUAN}

Pasar adalah area tempat jual beli barang dengan jumlah penjual lebih dari satu baik yang disebut sebagai pusat perbelanjaan, pasar tradisional, pertokoan, mall, plaza, pusat perdagangan maupun sebutan lainnya. Pasar tradisional adalah pasar yang berupa tempat usaha yang berbentuk toko, kios, los, dan tenda yang dimiliki/dikelola oleh pedagang kecil, menengah, koperasi dengan usaha skala kecil, modal kecil dan melalui proses jual beli barang dagangan dengan tawar-menawar.

Dibalik era perubahan yang terus-menerus terjadi, tentunya peluang usaha yang dapat dimanfaatkan secara optimal. Dalam hal ini usaha di sektor informal diharapkan mampu mengidentifikasikan peluang yang muncul akibat adanya perubahan tersebut.Lapangan kerja pada sektor formal menjadi prioritas bagi para tenaga kerja. Namun akibat adanya krisis ekonomi yang melanda Indonesia, banyak terjadi PHK pada sektor formal ini. Untuk itu perlu dikembangkan lapangan kerja pada sektor informal. Bahwa kelihatannya sektor informal tidak mampu menampung tenaga kerja seperti harapan kita, pada kenyataannya sektor informal bisa menjadi penyelamat bagi masalah ketenagakerjaan yang kita hadapi. Banyak bidang informal yang berpotensi untuk diangkat dan digali menjadi salah satu bidang usaha yang menghasilkan keuntungan dan pendapatan keluarga sekaligus dapat menyerap tenaga kerja ( Suryananto, 2005)

Perkembangan kota-kota ini dipengaruhi oleh beberapa faktor penting, Salah satunya adalah faktor perdagangan. Semakin pesatnya perkembangan kota dan semakin meningkatnya aktivitas perdagangan, maka hal ini dapat mempengaruhi laju pertumbuhan ekonomi pada kota tersebut. Semakin maju dan berkembangnya kondisi perekonomian kota tersebut, maka semakin mendorong adanya urbanisasi penduduk yang lebih besar dari desa menuju kota. Jika hal ini tidak diimbangi dengan adanya pembangunan di daerah pedesaan, maka akan mengakibatkan ketidakseimbangan pertumbuhan antara kota dengan desa.

Ketidak seimbangan tersebut akan mengakibatkan terganggunya interaksi yang terjadi antara daerah pedesaan dan kawasan perkotaan. Padahal, dapat dikatakan bahwa desa merupakan penyokong kehidupan di kota. Desa merupakan produsen dan penyuplai kebutuhan-kebutuhan pokok bagi masyarakat kota. Interaksi yang terjadi antara daerah pedesaan dan Oleh masyarakat pedesaan khususnya, pasar tradisional Sungai Saren digunakan sebagai tempat membeli kebutuhan sehari-hari. Selain itu, pasar tradisional Sungai Saren juga digunakan sebagian masyarakat untuk mencari penghasilan guna memenuhi kebutuhan sehari-hari. Hal ini oleh sebagian masyarakat dalam mencari penghasilan dengan berbagai macam cara, ada yang menjual kebutuhan sehari-hari dan ada juga yang menjual jasanya kepada calon pembeli.

Berkaitan dengan hal ini, desa sebagai produsen utama kebutuhan pokok bagi masyarakat kota memerlukan sebuah tempat yang dapat digunakan sebagai sarana pendistribusian barang-barang kebutuhan pokok tersebut. Salah satu tempat yang dapat mengakomodasi kegiatan distrbusi barang kebutuhan pokok tersebut adalah pasar. Pasar merupakan tempat bertemunya penjual dan pembeli untuk melakukan proses jual beli. Sehingga nantinya pasar dapat digunakan sebagai pusat perdagangan dan tempat pendistribusian barang antara produsen dan konsumen.

Berkaitan dengan hal ini, desa sebagai produsen utama kebutuhan pokok bagi masyarakat kota memerlukan sebuah tempat yang dapat digunakan sebagai sarana pendistribusian barang-barang kebutuhan pokok tersebut. Salah satu tempat yang dapat mengakomodasi kegiatan distrbusi barang kebutuhan pokok tersebut adalah pasar. Pasar 
merupakan tempat bertemunya penjual dan pembeli untuk melakukan proses jual beli. Sehingga nantinya pasar dapat digunakan sebagai pusat perdagangan dan tempat pendistribusian barang antara produsen dan konsumen.

Pasar dalam arti sempit adalah tempat permintaan dan penawaran bertemu, dalam hal ini lebih condong ke arah pasar tradisional. Sedangkan dalam arti luas adalah proses transaksi antara permintaan dan penawaran, dalam hal ini lebih condong ke arah pasar modern. Permintaan dan Penawaran dapat berupa Barang atau Jasa. Sedangkan secara umum pasar merupakan tempat pertemuan antara penjual dan pembeli.

Usaha berdagang merupakan salah satu alternatif lapangan kerja informal, yang ternyata banyak menyerap tenaga kerja, seperti pedagang pasar tradisional. Kegiatan perekonomian dari sektor tradisional masih menjadi kegiatan jual beli yang terus bertahan di tengah-tengah persaingan era globalisasi sekarang ini. Salah satu kegiatan perekonomian dari sektor tradisional ini adalah adanya kegiatan jual beli yang berada di pasar tradisional.

Masyarakat pedesaan khususnya, pasar tradisional Sungai Saren digunakan sebagai tempat membeli kebutuhan sehari-hari. Selain itu, pasar tradisional Sungai Saren juga digunakan sebagian masyarakat untuk mencari penghasilan guna memenuhi kebutuhan sehari-hari. Hal ini oleh sebagian masyarakat dalam mencari penghasilan dengan berbagai macam cara, ada yang menjual kebutuhan sehari-hari dan ada juga yang menjual jasanya kepada calon pembeli.

Pasar tradisional merupakan salah satu lokasi yang menjadi objek penggerak perekonomian khususnya di daerah setempat jika dikelola dengan baik oleh instansi terkait. Karena tidak sedikit masyarakat yang melakukan transaksi perdagangan, baik barang dan jasa. Sektor informal dalam hal ini pedagang pasar tradisional dalam usahanya mendapatkan pendapatan banyak dipengaruhi oleh faktorfaktor antara lain: modal usaha, Lokasi dan Tempat usaha. Faktor -faktor tersebut dengan sendirinya atau bersama-sama mempengaruhi pendapatan yang diperoleh pedagang.Dengan bertitik tolak pada masalah yang dihadapi oleh masyarakat yang berkeinginan untuk memenuhi kebutuhan hidupnya di sektor informal, karena kurangnya lapangan pekerjaan di sektor formal khususnya di Kecamatan Bram Itam. Berdasarkan latar belakang tersebut, penelitian ini bertujuan untuk menganalisis: 1.Bagaimana Kondisi Sosial dan Ekonomi Pedagang Pasar Sungai Saren Kecamatan Bram Itam Kabupaten Tanjung Jabung Barat secara Simultan dan 2.Bagaimana Pengaruh Modal, Harga Barang, Pendidikan dan Jam Kerja Terhadap pendapatan Pedagang Pasar Sungai Saren Kecamatan Bram Itam Kabupaten Tanjung Jabung Barat

\section{METODE}

Data yang digunakan dalam penelitian ini adalah data ini diambil langsung dari nelayan yang terpilih sebagai sampel, pengambian dilakukan dengan wawancara langsung pada responden dengan menggunakan daftar pertanyaan yang terpola dan terstruktur sesuai dengan kebutuhan.

\section{Jenis dan sumber data}

Data Primer adalah data yang diperoleh secara langsung dari sumber asli (tanpa perantara). Data primer yang ada dalam penelitian ini diperoleh langsung dari hasil penyebaran Kuisioner pada sampel yang telah ditentukan. Data ini diambil langsung dari nelayan yang terpilih sebagai sampel, pengambian dilakukan dengan wawancara 
langsung pada responden dengan menggunakan daftar pertanyaan yang terpola dan terstruktur sesuai dengan kebutuhan.

\section{Penarikan sampel}

Metode penarikan sampel yang digunakan adalah: Populasi merupakan gabungan dari seluruh elemen yang berbentuk peristiwa, hal atau orang yang memiliki karekteristik yang serupa yang menjadi pusat perhatian seorang peneliti karena itu dipandang sebagai sebuah semesta penelitian.Menurut Sugiyono (2017) Populasi adalah wilayah generalisasi yang terdiri dari atas obyek atau subyek yang mempunyai kualitas dan karakteristik tertentu yang ditetapkan oleh peneliti untuk dipelajari dan kemudian ditarik kesimpulannya, dalam hal ini:

Populasi dalam penelitian ini Pedagang Pasar Tradisional Sungai Saren Kecamatan Bram Itam Kabupaten Tanjung Jabung Barat, berjumlah 65 orang Pedagang. Metode yang digunakan dalam penelitian ini adalah metode Purposive Sampling yaitu suatu tipe samplng probaibilitas dimana peneliti dalam penarikan sampel dengan dipilih secara sengaja.Rumus yang digunakan untuk menentukan sampel pada penelitian ini dengan menggunakan rumus SLOVIN.

Dimana

$$
n=\frac{N}{1+N\left(e^{2}\right)}
$$

$\mathrm{n}=$ Jumlah Sampel

$\mathrm{N}=$ Jumlah Populasi

$\mathrm{e}=($ Error tolerance $)=5 \%(0,05)$

Jumlah penelitian ini menarik sampel sebanyak 56 orang dari populasi di Pasar Tradisional Sungai Saren Kecamatan Bram Itam Kabupaten Tanjung Jabung Barat.

\section{Analisis data}

Analisis data dilakukan secara deskriptif adalah analisis digunakan untuk memberikan gambaran atau deskripsi atas data yang dikumpulkan dalam penelitian. Dalam penelitian ini menggunakan angka indeks yang digunakan untuk mengetahui persepsi umum responden mengenai variabel yang diteliti. Analisis ini digunakan dengan cara menggambarkan atau menskripsikan data yang telah terkumpul sebagaimana adanya tanpa bermaksud membuat kesimpulan secara umum. Model regresi berganda adalah analisis ini untuk mengetahui arah hubungan antara variabel bebas dengan variabel terikat apakah masing-masing variabel bebas berhubugan positif atau negatif dan untuk memprediksi nilai dari variabel terikat apabila nilai variabel bebas mengalami kenaikan atau penurunan. Persamaan sebagai berikut (Sugiono, 2004):

\section{Dimana :}

$$
Y=\alpha+\beta_{1} X_{1}+\beta_{2} X_{2}+\beta_{3} X_{3}+\beta_{4} X_{4+} e
$$

$$
\begin{array}{ll}
\mathrm{Y} & =\text { Pendapatan Perdagangan } \\
\mathrm{X} 1 & =\text { Modal } \\
\mathrm{X} 2 & =\text { Umur } \\
\mathrm{X} 3 & =\text { Pendidikan } \\
\mathrm{X} 4 & =\text { Jam Kerja } \\
\alpha & \left.=\text { Konstanta (nilai Y' apabila } \mathrm{X}_{1}, \mathrm{X}_{2} \ldots \ldots \mathrm{X}_{\mathrm{n}}=0\right) \\
\beta_{1} \beta_{2} & =\text { Koefisien regresi (nilai peningkatan ataupun penurunan } \\
\mathrm{e} & =\text { Standar error. }
\end{array}
$$




\section{HASIL DAN PEMBAHASAN}

\section{Karakteristik sosial}

Kondisi sosial yang dimaksud dan dibahas dalam penelitian ini berupa, umur, pendidikan dan jam kerja pedagang pasar tradisional Sungai Saren Kecamatan Bram Itam Kabupaten Tanjung Jabung Barat.

\section{Umur}

Umur merupakan salah satu faktor yang dapat dijadikan ukuran untuk mengetahui usia berapa yang cenderung lebih besar untuk bekerja dan berusaha untuk berjualan, karena berdagang sangat membutuhkan tenaga dan pengalaman pedagang sejak usia muda.

Tabel 1. Jumlah dan persentase menurut tingkat umur.

\begin{tabular}{|c|c|c|}
\hline Umur/Usia Pedagang & Jumlah (Orang) & Persentase $(\%)$ \\
\hline $30-39$ & 2 & 3,57 \\
\hline $40-45$ & 11 & 19,65 \\
\hline $46-50$ & 15 & 26,79 \\
\hline $51-55$ & 14 & 25,00 \\
\hline $56-60$ & 13 & 23,21 \\
\hline $61-65$ & 1 & 1,78 \\
\hline Jumlah & 56 & 100,00 \\
\hline
\end{tabular}

Sumber: Data Primer yang diolah tahun 2019.

Berdasarkan tabel 1 dapat dijelaskan bahwa pedagang di pasar trasdisional Sungai Saren Kecamatan Bram Itam Kabupaten Tanjung Jabung Barat didominasi oleh banyaknya penduduk yang berusia 46-50 Tahun yaitu sebanyak 15 Orang atau sebesar $27 \%$, dan terkecil pedagang yang rata-rata berumur 61-65 tahun yaitu sebanyak 1 Orang.

\section{Pendidikan}

Tingkat pendidikan pedagang di pasar tradisional Sungai Saren masih tergolong rendah yaitu sekolah dasar hingga tidak menyentuh bangku pelajaran sama sekali, merupakan bagian besar dijenjang pendidikan yang pernah ditempuh, jadi tingkat pendidikan pedagang tidak berpengaruh secara signifikan terhadap pendapatan pedagang. Pedagang yang tingkat pendidikannya lebih tinggi belum tentu lebih mahir dalam berdagang dari pedagang yang tingkat pendidikannya lebih rendah. Dan menjadi seorang pedagang pendidikan tidaklah begitu penting, karena seorang pedagang diperlukan keahlian dan pengalaman dalam transaksi jual beli.

Tabel 2. Jumlah dan persentase menurut tingkat pendidikan pedagang pasar tradisional Sungai Saren

\begin{tabular}{ccc}
\hline Pendidikan Pedagang & Jumlah & Persentase (\%) \\
\hline Tidak sekolah & 6 & 10,71 \\
SD & 21 & 37,50 \\
SMP & 15 & 26,79 \\
SMA & 14 & 25,00 \\
\hline Jumlah & $\mathbf{5 6}$ & $\mathbf{1 0 0 , 0 0}$ \\
\hline
\end{tabular}

Sumber: Data Primer yang diolah tahun 2019. 
Tabel 2 menunjukkan bahwa pedagang pasar Tradisional Sungai Saren rata-rata tergolong pada Pendidikan rendah, Pendidikan terkhir mayoritas pedagang adalah Sekolah Dasar sebanyak 21 orang, hal ini disebabkan karena kurangnya kesadaran masyarakat untuk melanjutkan pendidikan ke jenjang yang lebih tinggi.

\section{Jam kerja}

Jam kerja merupakan hal yang paling mendominasi pendapatan pedagang Pasar Sungai Saren, semakin sedikit jam kerja semakin sedikit yang diambil maka pendapatan pun akan semakin sedikit

Tabel 3. Jumlah dan persentase menurut tingkat jam kerja di pasar tradisional Parit 2

\begin{tabular}{ccl}
\hline Jam Kerja & Jumlah (Orang) & Persentase (\%) \\
\hline 3 & 2 & 3,63 \\
4 & 23 & 41,07 \\
5 & 9 & 16,07 \\
6 & 13 & 23,21 \\
7 & - & 0.00 \\
8 & 9 & 16,07 \\
\hline Jumlah & $\mathbf{5 6}$ & $\mathbf{1 0 0 . 0 0}$
\end{tabular}

Sumber: Data Primer yang diolah tahun 2019

Berdasarkan tabel diatas, dapat dijelaskan bahwa pedagang di pasar trasdisional Sungai Saren didominasi dengan Jam kerja terbanyak 4 jam perhari sebanyak 23 Orang, dan sedikitnya pedagang yang jam kerja 3 jam perhari yaitu sebanyak 2 Orang.

\section{Karakteristik ekonomi}

Karakteristik Ekonomi yang dimaksud dan dibahas dalam penelitian ini berupa modal dan pendapatan pedagang pasar tradisional Sungai Saren, Kecamatan Bram Itam, Kabupaten Tanjung Jabung Barat.

\section{Modal}

Perencanaan dalam memulai usaha menjadi salah satu penentu keberhasilan usaha, modal awal merupakan bagian dari suatu perencanaan yang harus dipenuhi, tanpa adanya biaya awal maka usaha tersebut tidak akan berjalan dengan baik. Biaya awal yang diperlukan oleh pedagang pasar tradisional dapat dilihat pada tabel berikut ini:

Tabel 4. Jumlah dan persentase menurut modal awal pedagang pasar tradisional Sungai

Saren

\begin{tabular}{lcl}
\hline Modal Usaha (Rp) & Jumlah (Orang) & Persentase (\%) \\
\hline$<1.999 .999$ & 17 & 30,36 \\
2000.000 s.d 2999.999 & 12 & 21,42 \\
3000.000 s.d 3999.999 & 21 & 37,50 \\
$>4000.000$ & 6 & 10,72 \\
\hline Jumlah & $\mathbf{5 6}$ & $\mathbf{1 0 0 , 0 0}$ \\
\hline
\end{tabular}

Sumber: Data Primer yang diolah tahun 2019. 
Tabel 4 dapat disimpulkan bahwa saat memulai aktivitas perdagangang, pedagang banyak menggunakan modal awal sebesar Rp.3000.000 s.d 3999.999/Hari yaitu sebanyak

21 orang atau 38\% dari sampel pada penelitian ini, Dan menggunakan biaya tertinggi sebesar Rp.4000.000 s.d 5000.000 Berjumlah 6 orang atau sebesar 11\%, yang menggunakan biaya rendah <Rp.1999.999Berjumlah 17 orang atau sebesar 30\%.

\section{Pendapatan}

Pendapatan adalah jumlah uang yang diterima oleh pedagang dari aktivitasnya, kebanyakan dari penjualan produk dan/atau jasa kepada pelanggan, bagi investor pendapatan kurang penting dibandingkan keuntungan, yang merupakan jumlah yang diterima setelah dikurangi pengeluaran. Pendapatan sangat berpengaruh bagi kelangsungan hidup perusahaan, semakin besar pendapatan yang diperoleh maka semakiin besar kemampuan perusahaan untuk membiayai segala pengeluaran dan kegiatan-kegiatan yang dilakukan oleh perusahaan.

Pendapatan masyarakat pedagang pasar tradisional Sungai Saren bergantung tarhadap konsumen, dibidang penjualan maka sangat bergantung kepada hasil laut dan perkebunan, pendapatan masyarakat secara langsung ataupun tidak akan sangat mempengaruhi kuallitas dan kesejahteraan hidup mereka, karena pendapatan dari hasil penjualan merupakan sumber pemasukan utama atau bahkan satu-satunya bagi mereka, sehingga besar kecilnya pendapatan akan sangat mempengaruhi kesejahteraan kehidupan mereka.

Pendapatan bersih pedagang pasar tradisional sungai saren Kecamatan Bram Itam dapat ditunjukkan pada penghasilan atau pendapatan dalam sehari dikurangi dengan biaya upah tenaga kerja dan sewa lapak serta modal. Adapun pendaptan bersih Pedagang Pasar Tradisional Sungai Saren Kecamatan Bram Itam dapat dilihat dari jumlah persentase menurut Kelompok Pedagang Perhari.

Tabel 5. Jumlah persentase menurut pendapatan bersih pedagang pasar tradisional Sungai Saren

\begin{tabular}{lcc}
\hline Pendapatan (Rp) & Jumlah (Orang) & Persentase (\%) \\
\hline$<299.999$ & 17 & 30,35 \\
300.000 s.d. 399.999 & 29 & 51,79 \\
$>400.000$ & 10 & 17,86 \\
\hline
\end{tabular}

Sumber: Data Primer yang diolah tahun 2019

Tabel 6 menunjukan bahwa jumlah Pendapatan Pedagang Pasar Tradisional lebih banyak yang berpendapatan Rp. 300.000 s.d 399.999/hari yaitu berjumlah 29 orang atau $52 \%$ dari seluruh jumlah sampel yang diteliti. Sedangkan yang pendapatan rendah $<\mathrm{Rp}$. 299.999/hari berjumlah 17 orang atau 30\% dan yang berpendapatan tinggi Rp. 400.000 s.d 500.000 Sebanyak 10 orang atau $18 \%$.

\section{Faktor-faktor yang mempengaruhi pendapatan pedagang pasar tradisional}

Faktor-Faktor yang mempengaruhi pendapatan pedagang pasar tradisional dalam penelitian ini antara lain: modal (x1), umur (x2), pendidikan (x3) dan jam kerja (x4). Pengaruh secara simultan variabel bebas terhadap variabel terikat berdasarkan hasil perhitungan tersebut diperoleh persamaan sebagai berikut: 
Tabel 6. Hasil regresi linear berganda

\begin{tabular}{clccl}
\hline Variabel & \multicolumn{1}{c}{ Coefficient } & Std. Error & t-Statistik & \multicolumn{1}{c}{ Prob } \\
\hline X1 & 0.040 & 0.007 & 5.861 & 0 \\
X2 & 4.038 & 1.071 & 3.769 & 0.000 \\
X3 & 17.567 & 6.247 & 2.812 & 0.007 \\
X4 & 16.357 & 4.092 & 3.997 & 0.000 \\
R-squared & 0.520 & & F-statistic & 13.835 \\
& & & Prob(F-statistic) & 0.000
\end{tabular}

Sumber: Data diolah, 2019.

$$
\begin{gathered}
Y=b 0+b 1 X 1+b 2 X 2+b 3 X 3+b 4 X 4 \\
Y=293.188+0.040 X_{1}+4.038 X_{2}+17.567 X_{3}+16.357 X_{4}
\end{gathered}
$$

Berdasarkan hasil regresi linear berganda koofisien konstanta sebesar 293.188, ini dapat diartikan bahwa jika variable-variabel independent dianggap Konstanta maka Pendapatan Pedagang Pasar Tradisional Sungai Saren mengalami penurunan sebesar 293.188. Dari penjelasan tersebut, koofisien regresi masing-masing variable dependent (pendapatan), dan variabel independent adalah (modal, umur, pendidikan dan jam kerja) dapat dijelaskan sebagai berikut:

Nilai Koefisien Konstanta sebesar 293.188, ini dapat diartikan bahwa jika variable-variabel independent dianggap konstant maka rata-rata pendapatan pedagang pasar tradisional Sungai Saren sebesar Rp. 293.188. Koefisien dari variabel modal adalah 0.040 dan bernilai positif. apabila terjadi peningkatan modal sebesar rp.1. maka pendapatan pedagang meningkat sebesar rp.0.40. Koefisien dari variabel umur adalah 4.038 dan bernilai positif. apabila terjadi peningkatan umur pedagang lebih muda 1 tahun, maka pendapatan pedagang akan meningkat sebesar rp. 4.038. koefisien dari variabel pendidikan adalah 17.567 dan bernilai positif. Apabila terjadi peningkatan pendidikan, maka pendapatan pedagang akan meningkat sebesar Rp. 17.567. Koefisien dari variabel Jam Kerja adalah 16.357 dan bernilai positif. Apabila terjadi peningkatan jam kerja selama 1 jam/hari, maka pendapatan pedagang akan meningkat sebesar Rp. 16.357.

\section{Uji F}

Uji F digunakan untuk menguji hipotesis secara bersama-sama, maka digunakan uji f. uji f ini menguji signifikan variabel yaitu, modal, umur, pendidikan dan jam kerja secara bersama-sama berpengaruh terhadap variabel dependent yaitu pendapatan. uji statistik secara serentak ditunjukkan oleh perbandingan nilai $F$ Hitung $>F$ Tabel. Nilai $F$ tabel dengan $\mathrm{df}=(\mathrm{K}-1, \mathrm{n}-\mathrm{k})$, dengan derajat kepercayaan $95 \%$ adalah $F_{0,05}$ adalah $\mathrm{F}$ tabel sebesar 2.400. Dari hasil analisis didapat hasil F hitung sebesar 13.835 adalah jauh lebih besar dari $\mathrm{F}$ tabel. Berdasarkan taraf signifikan pada 0,000. Ini berarti menunjukkan bahwa keempat variabel Independent berpengaruh signifikan terhadap pendapatan pedagang pasar tradisional Sungai Saren Kecamatan Bram Itam. 


\section{Uji t}

Uji Statistik secara parsial dengan nilai t kritis (Critical Value) pada $\mathrm{df}=(\mathrm{n}-\mathrm{k})$, dimana $\mathrm{n}$ adalah jumlah observasi dan $\mathrm{k}$ variabel independent dan variabel dependent. berdasarkan hasil estimasi pada regresi, didapat bahwa dari variabel independent modal (x1), umur ( $\left.\mathrm{x}_{2}\right)$, pendidikan (x3) dan jam kerja (x4) berpengaruh signifikan terhadap pendapatan pedagang pasar tradisional Sungai Saren Kecamatan Bram Itam. Modal berdasarkan Probalitasnya maka jika Probalitasnya $>0,05$ maka Ho diterima dan jika probalitasnya $<0,05$ maka Ho ditolak. Dari hasil perhitungan diketahui signifikan adalah 0,000<0,05, artinya Modal pedagang berpengaruh signifikan terhadap Pendapatan Pedagang Pasar Tradisional Sungai Saren Kecamatan Bram Itam. Umur berdasarkan Probalitasnya maka jika Probalitasnya $>0,05$ maka Ho diterima dan jika probalitasnya $<0,05$ maka Ho ditolak. Hasil perhitungan diketahui signifikan adalah $0,000<0,05$, artinya Umur berpengaruh signifikan terhadap pendapatan pedagang pasar tradisional Sungai Saren Kecamatan Bram Itam. Pendidikan berdasarkan Probalitasnya maka jika Probalitasnya $>0,05$ maka Ho diterima dan jika probalitasnya <0,05 maka Ho ditolak. Hasil perhitungan diketahui signifikan adalah $0,007<0,05$, artinya pendidikan pedagang berpengaruh signifikan terhadap pendapatan pedagang pasar tradisional Sungai Saren Kecamatan Bram Itam. Jam kerja berdasarkan Probalitasnya maka jika Probalitasnya $>0,05$ maka Ho diterima dan jika probalitasnya $<0,05$ maka Ho ditolak. Hasil perhitungan diketahui signifikan adalah $0,000<0,05$, artinya jam kerja berpengaruh signifikan terhadap pendapatan pedagang pasar tradisional Sungai Saren Kecamatan Bram Itam.

\section{Koefisien determinasi $\left(\mathbf{R}^{2}\right)$}

Koefisien Determinasi digunakan untuk menguji goodness-fit dari model regresi dapat dilihat dari nilai $R$ Square, untuk mengetahui pendapatan pedagang pasar tradisional Sungai Saren Kecamatan Bram Itam dipengaruhi beberapa faktor yaitu modal, harga barang, pendidikan dan jam kerja melalui besarnya koefisien deterninasi. Perhitungan nilai $R$ square adalah 0,520 . hal ini berarti $52 \%$ modal, umur, pendidikan dan jam kerja mempengaruhi pendapatan pedagang pasar tradisonal Sungai Saren Kecamatan Bram Itam.

\section{Variabel modal}

Berdasarkan Probalitasnya maka jika probalitasnya $>0,05$ maka Ho diterima dan jika probalitasnya $<0,05$ maka Ho ditolak. Dari hasil perhitungan diketahui signifikan adalah $0,000<0,05$, artinya modal pedagang berpengaruh signifikan terhadap pendapatan pedagang pasar tradisional Sungai Saren Kecamatan Bram Itam.

\section{KESIMPULAN DAN SARAN kesimpulan}

Kondisi sosial ekonomi pedagang pasar tradisional Sungai Saren Kecamatan Bram Itam Kabupaten Tanjung Jabung Barat, dengan hasil rata-rata tiaptiap variabel. Variabel modal dengan hasil rata-rata rp 3000.000 s.d 4000.000/pedagang yaitu sebanyak 21 orang, variabel pendidikan rata-rata Sekolah Dasar dengan jumlah 21 orang, variabel jam kerja rata-rata 4 jam/Hari. Hasil regresi variabel modal, umur, pendidikan dan jam kerja berpengaruh positif dan signifikan terhadap pendapatan pedagang pasar tradisional Sungai Saren Kecamatan Bram Itam Kabupaten Tanjung Jabung Barat. 


\section{Saran}

Berdasarkan hasil penelitian dan kesimpulan, maka penulis memberikan beberapa saran, agar dapat mendorong dan mengembangkan pendapatan pedagang pasar tradisional Sungai Saren Kecamatan Bram Itam Kabupaten Tanjung Jabung Barat. 1) Untuk mendorong peningkatan pendapatan pedagang pasar tradisional Sungai Saren Kecamatan Bram Itam Kabupaten Tanjung Jabung Barat, kepada pemerintah dapat bekerjasama untuk memberikan dukungan dan bantuan seperti modal usaha bagi pedagang, yang pada umumnya pedagang pasar tradisional tidak memiliki banyak modal atau tergolong sangat rendah dan tidak dapat menutupi biaya yang digunakan untuk konsumsi rumah tangga. 2) Diperlukan solusi atau bantuan kebijakan pemerintah utuk lebih memikirkan kesejahteraan pedagang pasar tradisional, karena dilihat dari pasar modern sangat menyulitkan pedagang pasar tradisional selain dari tempat yang kotor dan juga lapak yang terbuat dari kayu sehingga pembeli lebih berbelok kepada tempat yang lebih praktis dan instan dan meninggalkan pasar tradisional yang sebenarnya itu adalah termasuk peninggalan leluhur yang harus dilestarikan.

\section{DAFTAR PUSTAKA}

Bambang. (2009). Akuntansi Manajemen. BPFE: Yogyakarta.

Baridwan, Zaki. (2010). Sistem Akuntansi Penyusunan Prosedur dan Metode. Edisi kelima. BPFE: Yogyakarta

C. Rollin, Niswonger, Carl S. Warren, Philip E. Fess. (1992). Prinsip-prinsip Akuntansi. Alih Bahasa Alfonsus Sirait. Jilid Satu. Edisi 16. Penerbit Erlangga: Jakarta. Charles, P. Jones. (1995). Invesment Analysist and Management. Edisi Kesembilan. John Wliley\&Sons Inc: New York.

Dyckman Thomas R, Roland E. Dukes, Charles J. Davis. (2002). Akuntansi Intermediate. Edisi Kesepuluh. Jilid Satu Terjemahan Emil Salim. Erlangga: Jakarta. Harahap, Sofyan Safri. (2002). Teori Akuntansi Laporan Keuangan. Bumi Aksara: Jakarta.

Hentiani, Tri. (2011). Analisis Faktor-Faktor yang Mempengaruhi Pendapatan Pedagang Informal di Pajak Sentral Medan. Skripsi. Medan: Repository Usu

Hurlock, E. B. (1992). Psikologi Perkembangan, Suatu Pendekatan Sepanjang Rentang Kehidupan. Erlangga Khatimah: Jakarta.

John J. Wild. (2003). Financial Accounting: Information For Decisions. Edisi Kedua. Diterjemahkan oleh Yanivi S. Bachtiar. Salemba Empat: Jakarta. Kasmir. (2006). Kewirausahaan. Raja Grafindo Persada: Jakarta.

Kuswandi. (2006). Memahami Rasio Rasio Keuangan Bagi Orang Awam. PT. Elex Media Kumpotindo: Jakarta.

Kusnadi. (2000). Akuntansi Keuangan Menegah (Prinsip, Prosedur, dan Metode). Edisi Kedua Puluh Satu. Salemba Empat: Jakarta. 